\title{
INDONESIA'S POSITION BASED ON THE AUSTRALIAN ASEAN NEW ZEALAND FREE TRADE AGREEMENT AND ITS IMPACT FROM A BUSINESS LAW PERSPECTIVE
}

\author{
Ariawan Gunadi ${ }^{1}$
}

\begin{abstract}
Indonesia as one of the major countries in South East Asia acts as a prominent business center between the East and the West. Business activities soon attract the attention of other countries in similar geography to share the wealth such as Malaysia, Filipina, Myanmar, Cambodia, Singapore, Vietnam, Thailand, Laos, Myanmar and Brunei Darussalam. However, the international society would have to face the import taxes that impedes foreign goods from flowing into state member' market. Australia and New Zealand as a fellow business partner then proposes the Australian Asean New Zealand Free Trade Agreement (AANZFTA) to the Association of South East Asian Nations (ASEAN) that allows members to conduct free trade among them in almost every sector, including goods, services, investment, intellectual property and new issues (Singapore Issues). However the agreement is suspected by some parties to condone a subtle form of liberal economy that may allow Australia and New Zealand to influence the national economy of the weaker state, not mentioning endangering ASEAN' bargaining position in the World Trade Organization. This article attempts to explain the position of Indonesia's economic sovereignty by signing the AANZFTA which imposes several clauses affecting the economic activity and how will the agreement bring impact to Indonesia's national economy of from a business law perspective.
\end{abstract}

Keyword: AANZFTA, Australia, business law, Indonesia

\section{Prologue}

As on of the largest countries in South East Asian region, Indonesia possess an important position among its neighbours. Some, if not most of the world's community relies on Indonesia to expand its international economic activity and sustain the world chain supply. With the ever growing business

1 Lecturer at Law Faculty of Tarumanagara University. Correspondence: ariawangun@gmail.com. 
development, the government has been an important element to regulate business activities while protecting its citizen's internest in form of legal instruments, including Indonesia.

Leaping forth to the 21 century, Australia dan New Zealand has long kept a vigilant eye for ASEAN's market potential to provide resources and market their goods. This led to the formation of AANZFTA draft as one of the most comprehensive agreements to be concluded between non ASEAN countries and ASEAN. In short, the agreement encompasses goods and services trade, electronic transaction (e-transaction), freedom of movements, investment issues, economic cooperations, dispute resolution mechanisms and procedures regarding customs, sanitation and phyto-sanitation including actions, standards and technicalities, intellectual property issues, dispute resolution mechanism and Singapore issues (new issues). ${ }^{2}$

Since the beginning of its discussion on November 2009, AANZFTA has received numerous comments from various parties. ${ }^{3}$

The pros supported this decision by stating more good than harm will come from this agreement include a potential for bigger markets with less or even no tariffs at all. Business scopes may well be integrated into a globally scaled and evolving supply line; the enactment of a consistent and transparent procedure will definitively support business and transaction activities, especially considering that Australia, New Zealand and ASEAN has had an interconnected business activity for quite some time.

Economic experts predicted that the presence of AANZTA will increase the business relations intensity among nations. Notably, the elements of AANZFTA possess a clear and futuristic vision, one that deliver ASEAN to a new phase in external relationship and internal integration as a regional organization powerful and stable enough in the South East Asian region. Investors will also reap the advantage of AANZFTA agreement regarding trade liberalization and protection in form of a definite investment rules, less investment barriers and a just dispute resolution mechanism that may apply regionally. ${ }^{4}$

On the other hand, defense against the AANZFTA stated that it will only open for a thorough liberalization for the depressed national economy,

${ }^{2}$ Sulaiman, World and Regional Trade Liberalization: Implications on ASEAN, Accessed at $<$ http://www.aseanlawassociation.org/9GAdocs/w3_Brunei.pdf $>$ : p. 4

3 Anonym, Media Fact-sheet ASEAN-Australia-New Zealand, <http://app.mti. gov.sg/AEM/default.asp?id=3226>, accesed 28 October 2008.

${ }^{4}$ Jones, Doug. Australia: ASEAN-Australia-New Zealand, Free Trade Agreement, $<$ http://www.mondaq.com/article.asp?articleid=76356>, accesed 19 Maret 2009. 
showing that the government would prefer to bow before foreign interest. If so, it would simply be a matter of time before the consumers are attracted to cheaper foreign goods, eventually dispatching local businesses one at a time. ${ }^{5}$

Even so, the Indonesian government represented by the Trade Minister, along with several ASEAN, Australian and New Zealand trade ministers had decided to sign the agreement on the $28^{\text {th }}$ of February 2009 , during the $14^{\text {th }}$ ASEAN summit in Hua Hin city, near Thailand. Truthfully, the agreement was designated to be signed on December 2008, but had seen repeated delays due to dispute from ASEAN members on the schedule for tariff lifting until the $27^{\text {th }}$ of Februari 2009.

Australia's intention was to expand in Indonesia's automotive products while New Zealand has been a long term advocate of a liberal market for dairy and beef products. Based on the agreement above, Indonesia will finally committed to open most of her markets including the three mentioned above by expecting a similar profitable return.

Along with the signing of the agreement, AANZFTA was perceived as a bear trap by developed countries to sway developing countries into the so called globalization issue. As a main weapon, it is uncommon for Indonesia's trading partner to put forward the promises of trade liberalization and investment in a wide array of agreements and economic cooperation whether in bilateral and multilateral forums such as the Japan Indonesia Economic Agreement (JIEPA), ASEAN Economic Community (AEC), North American Free Trade Agreement dan the World Trade Agreement. The most prominent examples in these agreements started by phased elimination of tariff barriers, trade barriers, investment barriers and special protection for foreign investors.

In line with the protesters of the free trade agreement, the Indonesian Chamber of Commerce/Kamar Dagang dan Industri (Kadin) and Indonesian Trade Association/Asosiasi Perdagangan Indonesia (Apindo) argued that Indonesia has no clear explicit benefit from the agreement, save for a capable legal instrument to protect her national industry from hordes of various foreign products, especially from Australia and New Zealand such as beef, cotton, coal and dairy products. ${ }^{6}$

As an information, the author believes that AANZFTA should be viewed in a moderate manner by regarding possible future consequences for

5 Gregory and Stuart, "Comparative Economic System", 4 ${ }^{\text {th }}$ Edition, (Boston: Houghton Mifflin Company, 1992), p. 29.

${ }^{6}$ Produk Australia Bebas Bea Masuk, Kadin: Bisa Banjir Komoditas Impor, $<$ http://cjfeed.co.id/index2.php?option=com_content\&do_pdf=1\&id=2756>, 7 July 2009. 
states to formulate national policies, since it is related with Indonesia's economic adaptability. Undoubtedly that economic globalization will bring forth a legal system globalization since the effect substantially affects various law instruments and even going transnational at an incredible speed. ${ }^{7}$

\section{Issues}

This article would like to view the state of Indonesia's economic sovereignty post the signing of AANZFTA agreement containing mechanism dispute resolution clauses which should be abided by the government and how would the agreement affect the national economic stability from a business law perspective.

\section{Discussion}

\section{A. The Philosophical Foundation for Indonesia's National Economy}

At glance, the government bears the responsibility to sustain the economy and improve public welfare as accorded in Article 33 (1) of the 1945 Constitution clearly stating that the national economy is governed based on the principle of a democratic economy with the principle of communal efficiency, justice, sustainability, independence and by considering the balance of improvement and national economic unity.

Article 34 (2) of the 1945 Constitution further elaborates that state develops a social security system for all of its citizen and empower the poor and unfortunates in accordance with humanitarian values.

Article 34 of the 1945 Constitution was established by her founders as a mean to faithfully conduct the duties of state to protect its constituents economy, which will in effect increase the national welfare, ideally targeting the lower tier of the society to prevent social clash.

If we were to observe Indonesia' process to her independence, the development process is an inherent part of the evolution to enhance the

${ }^{7}$ Erman Rajagukguk, Peranan Hukum dalam Pembangunan pada era Globalisasi: Implikasinya bagi Pendidikan Hukum di Indonesia, Inauguration speech as Professor at the University of Indonesia, Jakarta, 1997, p. 15. 
nation's spirit (volkgeist), which includes a legal process as an indigenous expression of the national culture, history of a people as expressed in their spirit and product of collective conscience. Djojonegoro commented the similar perspective on this issue since he stated the necessity for government to attend the development process seriously as a way to transform the society onto a better life. ${ }^{8}$

Arising from some of the theories above, the writer took a hypothesis that theoretically the development process in every sector, especially the economic sector, tends to rejuvenate the people's participation. The participation should be assisted with the increase of employment opportunities (for the people) and the benefits enjoyed by as much people as possible. But of course the development in theory could not deattach itself from the historical, social and cultural aspect which demands balance between person and environment (requiring interdependence process in the end). In part, (economic) development emphasizes on a democratic and not economic approach, since by doing so will promote society's participation in accordance with the living values in the society, whether in the development process or reaping the benefit. This kind of model would be suitable to be combined with the democratic realm of Indonesians, keeping in mind with the pluralistic traits of Indonesian history and culture that has bonded them for many centuries.

\section{B. Indonesia, Australia and New Zealand's Economic Relationship}

To date, Australia possesses Free Trade Agreement (FTA) with New Zealand, Thailand and Singapore, has yet to do so with Myanmar, Brunei Darussalam, Cambodia, Laos, Vietnam, Indonesia, Malaysia and Phillipines. On 2007-2008 itself, the amount of exportimport transactions between Indonesia and Australia reached up to 10,3 billion USD. ${ }^{9}$

New Zealand operates in 4 main markets across the South East Asian region which is Indonesia, Malaysia, Phillipines and Vietnam. With the reenactment of the AANZFTA agreement intending to tear

\footnotetext{
${ }^{8}$ Yahya M. Abdul Azis, ed., "Visi Global Antisipasi Indonesia Memasuki Abad ke 21", (Yogyakarta: Pustaka Pelajar, 1998), p. 76.

${ }^{9}$ Iain Sandford, Special Report, ASEAN Australia New Zealand Free Trade Agreement, accesed at $<$ http://www.theworldlawgroup.com/docs\%5CASEAN Australia $\% 20$ New\%20Zealand\%20Free\%20Trade\%20Agreement.pdf $>$, p. 4.
} 
down the trade barriers, the Kiwi country is set to export $99 \%$ of its products within 12 years time to the 4 countries. Experts feared that developing countries would be helpless to resist the onslaught since there has been no special rights agreed upon, especially to protect its cultural sovereignty, during or after the agricultural import fee has been eliminated. Some of the impacts of AANZFTA to Indonesia among others: ${ }^{10}$

1. Indonesia will eliminate its import tariff on powdered milk, ice cream and cheese from Australia and New Zealand by 2011 until 2020;

2. Indonesia will also eliminate its import tariff on meat and wool simultaneously (each at 2012 until 2020 and 2010). Malaysia had opted to grant a free access "locked in" status to New Zealand on meat and wool, meaning that Malaysia is prohibited from raising prices one-sidedly without New Zealand's approval;

3. In the forestry sector, Indonesia will eliminate its import tariff between 2012-2020 for fiber board and paper products.

4. Regarding horticultural sector, Indonesia will eliminate import tariffs for fruits and vegetables. Some of them include apple, kiwi and onions which is predicted to be in effect on 2010 .

5. Indonesia agreed to lay down its enforcement on local contents to imported machineries from Australia and New Zealand so that they may utilize a Completely Built Up (CBU) mechanism on products such as electrical tools, stativ converters, air conditioners, commercial refrigerators, toys, roadway construction equipment and billboards. Indonesia is also commited to eliminate the tariff products mentioned above from $15 \%$ to none at all from 2010 until 2013.

Despite AANZFTA effort to provide tariff elimination mechanism for certain import products, there are also excluded groups which is out of the ring. At this case, the products will be reduced based on tariff rate quota system or based on the Most Favoured Nation treatment. An example of this product is wine, seafood and steel, which the total estimated transaction reaches up to 15 million USD.

${ }^{10}$ Key Outcomes: Agreements establishing the ASEAN-Australia New Zealand Free Trade Area, <http://www.asean.fta.govt.nz/assets/Downloads/asean-key-outcomes.pdf>. 


\section{Indonesia's Action Relating to AANZFTA Import Policies}

According to the international law theory, a state may choose between 2 types of policies in abiding an international agreement The first theory would be the voluntarism theory in which the state agrees to abide an international agreement when it has signed the agreement. Followers of this agreement are America and England as common law states since their legal source was not based on acts but more to the unwritten law or gentleman agreement. ${ }^{11}$

The second theory would be the objective theory stating that a state shall not directly abide an international agreement, if not without according its national law. European Continental states such as Dutch and Indonesia rely on a written law basis as the maind source in managing a policy. An international law without the extension of a written law would only possess a moral value without any binding authorities. $^{12}$

Oppenheim-Lauterpacht supported the latter theory stating that a government should be sovereign, meaning that a free authority out of foreign influence to decide actions in te national or international realm. ${ }^{13}$

\section{AANZFTA's Effectiveness Within the International Law}

In analyzing the effectiveness of AANZFTA agreement in Indonesia, one should firstly observe the law policies being used. Dualism derives from the theory that states have the right to decide whether to accept or refuse an international law product in the national law and international law is considered to be 2 different realm. ${ }^{14}$

${ }^{11}$ Williams S.A. Mestral, de., "An Introduction to International Law”, (Toronto: Toronto Press, 1979), p. 78.

12 Mohamad Pan Faiz, Proses Pengesahan Perjanjian Internasional Menjadi Undang-Undang di Indonesia, <http://jurnalhukum.blogspot. com/2008/01/perjanjian-inter nasional2.html $>$, accesed 2 Januari 2008.

${ }^{13}$ Huala Adolf, “Aspek-Aspek Negara Dalam Hukum Internasional”, (Jakarta: PT. RajaGrafindo Persada, 2002), p. 7, and see: Oppenheim-Lauterpacht, "International Law: A Treatise", vol 1: Peace, $8^{\text {th }}$ Edition, (London: Longmans, 1967), p. 118.

p. 198.

${ }^{14}$ J.L. Brierly, "The Law of Nations", $5^{\text {th }}$ Edition, (Oxford: Clarendon Press, 1954), 


\section{Dualisme}

Dualism elaborates its standing based on the following

a. The system reflects on the standing that national law and international law comes from a different source. Whilst the national law emerged from the state's (people) intent the international law refers to the communal will of states as member of the international society;

b. The subject of national law, whether in common law or criminal law involves individual and business entities, while the international law tends to point at states as subject;

c. The legal institution in the national level (Indonesia) consists of the legislative, judicative and executive authorities with their distinct functions, while the international law is comprised on many different bodies and often hard to discern as a legal entity.

d. Basically, even though an international agreement had been agreed upon or violated by a state, the effect would not apply immediately to the perpetrator. This belief supported the thesis that the national law stands on a more solid ground than international law which merely "floats" on agreements.

Malenovsky argued that the international law and the national law are two completely different and separate systems, based not only on the jurisdiction and law enforcement entities but also legal sources and subjects.

Fitzmaurice held out his theorem on monism system by the name of "Fitzmaurice Compromise" to compare the two legal systems with the relations of two sovereign states. In case of conflict between both systems, a rule to arrange those conflicts will emerge to explain of how the problem may be settled according to the national court law of procedure. It is then when he opinionated that, "it is useless for scholars to ramble about international law supremacy in the international realm since the supremacy itself arise from the fact of its monocular presence there. The supremacy was not borne from the content of the agreement, but from the type of the agreement".

${ }^{15}$ Is the Dualist-Monist Controversy in International Law Simply a Fiction?, $<\mathrm{http}: / /$ mezinarodni2.juristic.cz/51001/clanek/mpv1>. 
To sum up his opinion, he stated that the national law instruments may or may not declare that an international agreement is at a higher level but the results will still be decided by according to the national law. ${ }^{16}$

\section{Monism}

According to Dixon, the national and international law are two similar components from a singular entity recognized as "law". The singularity arise from the reason where "national" and "international" version are manifestation at most. It is to his opinion that the international law should be placed on a higher position, which draw fire from several experts.

Hans Kelsen (a monist-positivist) opened the debate by viewing the international law supremacy as a direct consequence of its "basic norm" to lay out its legal instruements. This basic norm is about "hoe states should act as they have acted based on customs over the century". As impact, the international law represents a higher law since it derives from the practice done by states and extracted from their national practice. ${ }^{17}$

Lauterpacht continued the argumentation by praising international law as of a higher form since it offers a universal warrant from individual rights. States itself, according to him, are a group of individuals rather than a legal entity in its capacity. Perhaps this is due to the monist naturalist influence of his studies that appraised the international law supremacy from the natural law perspective that natural law should reside on the top of the pyramid, followed by international law and then natural law. ${ }^{18}$

The diverse opinion above being accumulated possess similar basic monistic value which considers that national and international law domiciles within the same group of law hierarchy and demanding a systematic norm based on scale

16 J.G., Fitzmaurice Gerald Merrills, "Judge Sir Gerald Fitzmaurice and The Discipline of International Law: Opinions on The International Court of Justice 1961-1973", (Boston: Kluwer Law International, 1998), p. 276.

${ }^{17}$ Hans Kelsen, "General Theory of Law \& State", Imported Edition, (New Delhi: Transaction Publishers, 2005), p. 105.

${ }^{18}$ Hersch Lauterpacht, "International Law, Being the Collected Papers of Hersch Lauterpacht", vol. 1, (London: Cambridge University Press, 1970), p. 216-230. 
priority to uphold the position of international law to a higher place. It is to this belief that the national law should come after the international law based on the delegation of authority from international law.

On reality, both of this theory was applied by states in determining the effectiveness of international law according to their respective practices. Indonesia herself adopts dualism approach in accommodating international law by referring to the law system inherited from the Dutch colonial government.

The drafting and signing of international agreements between the Indonesian government with other states, international organizations and other subjects of international law is deemed a very important occasion since it binds the state with other subjects of international law thus requiring the due process of law.

\section{E. Indonesia's Legal Instrument For International Agreement}

To date, Indonesia relies on Law No. 24 Year 2000 on Treaties to elaborate on the authorities of conducting an international agreement. The law is an extension of article 11 of the 1945 Constitution stating that the presiden has the authority to conduct international agreement with the approval from the House of Representatives.

The stages of ratifying an international agreement based on the elucidation of Law No. 24 Year 2000 is divided into 4 categories, which is:

1. Ratification process: the state which is a party to the agreement signs the international agreement;

2. Accesion: state party which is a member of the international agreement decided not to sign the international agreement;

3. Acceptance or Approval: the phase of accepting the text of agreement which has been drafted and agreed upon by the parties in terms of an international agreement or its amendment;

The content of Law No 24 Year 2000 comprises of the following:

1. General Provisions;

2. Conclusion of Treaties;

3. Ratification of Treaties;

4. Implementation of Treaties;

5. Depositary of Treaties;

6. Termination of Treaties;

7. Transitional Provisions; 


\section{Transitional Provisions.}

In accepting an international agreement, the signing process does not, in conclusion may be lawfully interpreted as a binding relation between state parties. The main stream used according to the Indonesian law would be to assimilate in a form of national law instruments by way of ratification, even though according to article 9 and 10 of Law No. 24 Year 2000, some cases self-executing agreements may be approved.

A Indonesian government representative with the purpose of signing an international agreement in or for the state to be bound by the agreement would require a Full Powers, except for Presidents and Ministers. Other exceptions would be if the representative were to sign an international agreement regarding technical cooperations as an execution from the already applicable agreement or whose matter is within the scope of a state institution, whether department or non department.

The ratification of an international agreement chronologically is based on joint agreement between both parties and is usually applicable after the ratification procedures have been fulfilled according to the national law which is in form of a law or presidential decree. Sim

The international agreement that does not require ratification in its application usually denotes technical issuance or consists of technical guidelines for the main agreement. This kind of international agreement may apply directly after the signing or exchange of documents/diplomatic notes or other methods agreed by both parties.

Agreements that enter this category, among others, include issues such as education, social, cultural, tourism, health information, agricultural, forestry or cooperation between provinces and cities. The international agreement will start to apply and bind the parties after accomplishing the stated regulations within the agreement.

Observing the case of AANZFTA, in which Indonesia has become a state party and also to sign the agreement, it is clearly stated:

Nothing in this Agreement shall preclude all Parties from negotiating and entering into arrangements to accelerate and or improve tariff commitments made under this Agreement .....Such acceleration and/or improvement of tariff commit-ments shall be implemented by all the parties.

The clause has clearly defined the commitment of all state parties, including Indonesia to stop the flow of tariff elimination concerning 
free trade. How will Indonesia counter the possible negative impact cause by the AANZFTA? Based on the dualism system, which Indonesia proposes, the AANZFTA will have to be promulgated in a national law that specifically mentions its ratification by the government. As an analogy, since Indonesia has ratified the United Nations Framework Convention on Climate Change at $21^{\text {st }}$ of March 1994, therefore it had enacted Law No 6 Year 1994 on the Ratification of United Nations Framework Convention on Climate Change by 1 August 2004 to pave a legal basis for the lower tier regulations on energy, mining and environmental fields.

\section{F. The Sociological Impact of AANZFTA to the Indonesian Economy}

Observing the agreement, the AANZFTA's purpose is to expand a medium scaled global economy on trade and investmen issues which condones to neoliberal economy theory. As a modified version and mixture between liberalism and capitalism, the theory marks the end of influence competition between liberalism-capitalism vs. socialismcommunism during the cold war era which was won by the liberal side. ${ }^{19}$ The victorious ideology then became the backbone of political economy movement by western countries and soon was interpreted to globalization and neoliberal side.

After the end of the cold war, the world was enveloped by an almost Unitarian ideology which is the neoliberal ideology as a political, economical, societal and cultural reference globally. The situation is knowledgeable since there was only one dominant ideology as a reference for interpretation on every aspect and the tendency of its enforcement to developing countries.

States would be persuaded to believe that they have gone way to deep in interfering with private life, inhibiting the people's effort to gain prosperity in an optimal manner. Therefore what the government should do is reduce their part in the political-economy and attend to the market mechanism to that the "wise invincible hands" may automatically regulate and create prosperity for the society. ${ }^{20}$

19 I. Hilier, "Sourcebook on Public International Law", $7^{\text {th }}$ Edition, (London: Cavendish Publishing Limited, 1998), p. 86.

20 Hubertus Müller Groeling, "Social Liberal Political Dimension”, (Potsdam: Friedrich-Naumann-Stiftung, 2001), p. 6. 
Liberal economy first theory was first voiced by Adam Smith stating that free market was the best option to support the economic growth of a nation. The idea then supported free enterprise and free competition system, which was meant as the freedom for capitalists to generate profits in an unlimited manner. As a trend, liberal economy spread like wild fire across America and most European countries from 1800 to the early $1990 \mathrm{~s}^{21}$

Destined to be a new variant of economic liberal movement, neoliberalism was born to rival the Keynesian economy system that has dominated the West for more than 30 years. The oil crises that started at the end of 1973 generated an economic recession, unemployment, inflation of more than $20 \%$ in several countries and even dragged Third world countries to a critical state since they were unable to pay their debt. Since that time, capitalistic countries viewed the Keynesian doctrine as a failure to the solution and even as the cause of the crisis. John Maynard Keynes, the advocate of this theory declared that government and central banks to hold part in the economy to create a full employment opportunity. However, some capitalist faction was inspired to revive the liberal economy belief since they assumed that government intervention in the economy would diminish their opportunity to gain profit. This idea soon became as the "new" or "neo" liberal system adopted by numerous countries. ${ }^{22}$

\section{Conclusion}

The enactment of an international agreement in Indonesia is based on either a law or presidential decree. Under the law it requires an approval from the House of Representatives, while under the presidential decree category, it would only require a notice to the House of Representatives.

The enactment of an international agreement is based on a law when concerning with:

1. matters pertaining to politics, peace, defense, and state security;

2. alterations to or delimitation of the territory of the Republic of Indonesia;

\footnotetext{
${ }^{21}<$ http://arifbastari.-multiply.com/journal $>$.

22 John. P. Conrad Waligorski, "Liberal Economics and Democracy: Keynes, Galbraith, Thurow and Reich (American Political Thought)", (Kansas: University Press of
} Kansas, 1996), p. 133. 
3. sovereignty or sovereign rights of a state;

4. human rights and the environment;

5. the formation of a new legal norm (Law making Treaty);

6. foreign loans and/or grants-aid.

Within the function an authority mechanism, the House of Representatives may inquire answers or reasoning from the government concerning the international agreement. If it is deemed harmful to the national interest, the House may ask the government to cancel the international agreement in accordance with Law No. 24 Year 2000, or politically refuse to assimilate it into a law, according to Article 9 (1) and (2) of the law stating that:

(1) Ratification of a treaty by the Government of the Republic of Indonesia shall be conducted provided it is required by the treaty.

(2) Ratification of a treaty as referred to in paragraph (1) shall be conducted by way of a law or a presidential decree.

Therefore the effectiveness of an international agreement to the international law does not follow automatically since Indonesia viewed the national and international law as 2 different and separate system between one another.

The birth of neoliberalism is unavoidable from the existence of Capitalism as an ideology. As a character, neo liberalism is based on "liberty" and emphasizes on "individual interest", operating economic activities according to the nature's law. English Philosopher, Herbert Spencer viewed survival of the fittest as a fundamental principle within the Capitalistic system. ${ }^{23}$

As consequence, the econmy runs by trampling on the weak and facilitating the strong (capital owners) to focus on resource allocation, along with market monopoly to capital owners.

Relating to the reviews above, the critic may not be justifiable as a whole, since it seems as if the neoliberal economy system has no social sense. However, it may be true due to the fact that the liberals refused to take part in extending the social collective network already established by the government.

${ }^{23}$ John Naisbit, "Global Paradox", (New York: William Morrow and Company, Inc., 1994), p. 98. 
Indonesia has ratified the AANZFTA agreemen on February 2009 as the beginning of free trade era from and to the Indonesia. The government should use the deadline provided until 2010 to consider the necessary legal actions to protect the national economic interest, which will then be drafted in the national law as a mean for protection against the AANZFTA. 


\section{Bibliography}

\section{Book}

Adolf, Huala. Aspek-Aspek Negara Dalam Hukum Internasional, Jakarta: PT. RajaGrafindo Persada, 2002.

Azis, Yahya M. Abdul, ed., Visi Global Antisipasi Indonesia Memasuki Abad ke 21, Yogyakarta: Pustaka Pelajar, 2009.

Brierly, J.L. The Law of Nations, $5^{\text {th }}$ Edition, Oxford: Clarendon Press, 1954.

Dixon, Martin. Textbook on International Law, $3^{\text {rd }}$ Edition, London: Sweet \& Max-well, 1996.

Hilier, I. Sourcebook on Public International Law, $7^{\text {th }}$ Edition, London: Cavendish Publishing Limited, 1998.

Merrills, J.G., Fitzmaurice, Gerald. Judge Sir Gerald Fitzmaurice and The Discipline of International Law: Opinions on The International Court of Justice 1961-1973, Boston: Kluwer Law International, 1998.

Gregory dan Stuart. Comparative Economic System, $4^{\text {th }}$ Edition, Boston: Houghton Mifflin Company, 1992.

Groeling, Hubertus Müller. Social Liberal Political Dimension,. Potsdam: Friedrich-Naumann-Stiftung, 2001.

Kelsen, Hans. General Theory of Law \& State, Imported Edition, New Delhi: Transaction Publishers, 2005.

Lauterpacht, Hersch. International Law, Being the Collected Papers of Hersch Lauterpacht, vol. 1, London: Cambridge University Press, 1970.

Malenovský, J. Mezinárodní právo veřejné, Brno: Doplněk Brno, 2004.

Mestral, Williams S.A., de., An Introduction to International Law, Toronto: Toronto Press, 1979.

Naisbit, John. Global Paradox, New York: William Morrow and Company, Inc., 1994.

Oppenheim-Lauterpacht. International Law: A Treatise, vol 1: Peace. $8^{\text {th }}$ Edition, London: Longmans, 1967.

Rajagukguk, Erman. "Peranan Hukum dalam Pembangunan pada era Globalisasi: Implikasinya bagi Pendidikan Hukum di Indonesia", 
Inauguration speech as Professor at the University of Indonesia, Jakarta, 1997.

Waligorski, John. P. Conrad. Liberal Economics and Democracy: Keynes, Galbraith, Thurow and Reich (American Political Thought), Kansas: University Press of Kansas, 1996.

\section{Internet}

Anonym. "Media Fact-sheet ASEAN-Australia-New Zealand", $<$ http://app.mti.gov.sg/AEM/default.asp?id=3226>, accesed 28 October 2008.

Anonym."Produk Australia Bebas Bea Masuk, Kadin: Bisa Banjir Komoditas Impor", <http://cjfeed.co.id/index2.php?option=com content\&do_pdf=1\&id=2756>, accesed 7 July 2009.

Anonym. "Key Outcomes: Agreements establishing the ASEAN-Australia New Zealand Free Trade Area", <http://www.asean.fta.govt .nz/assets/Downloads/asean-key-outcomes.pdf>, 2009.

Anonym. "Is the Dualist-Monist Controversy in International Law Simply a Fiction?", <http://mezinarodni2.juristic.cz/51001/clanek/mpvl>, 2009.

Anonym. $<$ http://arifbastari.-multiply.com/journal $>, 2009$.

Faiz, Mohamad Pan. "Proses Pengesahan Perjanjian Internasional Menjadi Undang-Undang di Indonesia", <http://jurnalhukum.blogspot. com/2008/01/perjanjian-internasional2.html>, accesed 2 Januari 2008.

Jones, Doug. "Australia: ASEAN-Australia-New Zealand, Free Trade Agreement", <http://www.mondaq.com/article.asp?articleid=76356>, accessed 19 Maret.

Sandford, Iain. "Special Report, ASEAN Australia New Zealand Free Trade Agreement", accesed at <http://www.theworldlawgroup.com/docs\% 5CASEANAustralia\%20New\%20Zealand\%20Free\%20Trade\%20 Agreement.pdf>, 2009.

Sulaiman. "World and Regional Trade Liberalization: Implications on $A S E A N ", \quad$ accessed at <http://www.aseanlawassociation.org/9GA docs/w3_Brunei.pdf>, 2009. 